\title{
Technological Transformation, Multiple Literacies, and the Re-Visioning of Education ${ }^{1}$ \\ Douglas Kellner \\ (http://www.gseis.ucla.edu/faculty/kellner/)
}

The dramatic multiplication of computer, information, communication, and multimedia technologies has been changing everything from the ways people work, to the ways they communicate with each other and spend their leisure time. This technological revolution is often interpreted as the beginnings of a knowledge or information society, and therefore ascribes education a central role in every aspect of life. It poses tremendous challenges to educators to rethink their basic tenets, to deploy the new technologies in creative and productive ways, and to restructure schooling to respond constructively and progressively to the technological and social changes currently underway. At the same time, important demographic and socio-political changes are taking place throughout the world. Emigration patterns have created the challenge of providing people from diverse races, classes, and backgrounds with the tools and competencies to enable them to succeed and participate in an ever more complex and changing world.

In this chapter, I argue that educators need to cultivate multiple literacies for contemporary technological and multicultural societies, that teachers need to develop new literacies of diverse sorts, including a more fundamental importance for print literacy, to meet the challenge of restructuring education for a hi-tech, multicultural society, and global culture. In a period of dramatic technological and social change, education needs to help produce a variety of types of literacies to make current pedagogy relevant to the demands of the contemporary era. As new technologies are altering every aspect of our society and culture, we need to comprehend and make use of them both to understand and transform our worlds. In particular, by introducing multiple 
literacies to empower individuals and groups traditionally excluded, education could be reconstructed to make it more responsive to the challenges of a democratic and multicultural society.

\section{Technology and the Re-Visioning of Education}

To dramatize the issues at stake, we should consider the claim that we are now undergoing one of the most significant technological revolutions for education since the progression from oral to print and book based teaching (Castells 1996, 1997, 1998, and Best and Kellner 2001). Just as the transition to print literacy and book culture involved a dramatic transformation of education (McLuhan 1962, 1964; Ong 1988; Illich and Sanders 1989), so too does the ongoing technological transformation demand a major restructuring of education today with novel curricula, pedagogy, literacies, practices, and goals. Furthermore, the technological developments of the present era makes possible the radical re-visioning and reconstruction of education and society argued for in the progressive era by Dewey and in the 1960s and 1970s by Ivan Illich, Paolo Freire, and others who sought radical educational and social reform. ${ }^{2}$

A re-visioning education requires a thorough examination and critique of dominant institutions of schooling, pedagogical practices, and the goals and ends of teaching. Technological change, globalization, and multicultural expansion all demand looking at things in new ways and looking back at how the world was before dramatic changes have occurred. Re-vision involves both critically seeing the past and present and imagining a different future. It implies as well reconstructing education, using informed theory to guide novel pedagogical practices and to fundamentally restructure educational institutions. Re-visioning education also involves another 
way of seeing and doing, grounded in historical practices of the present and looking toward a different and better future.

Put in historical perspective, it is now possible to see modern education as preparation for industrial civilization and minimal citizenship in a passive representative democracy. Modern education, in short, emphasizes submission to authority, rote memorization, and what Freire called the "banking concept" of education in which learned teachers deposit knowledge into passive students, inculcating conformity, subordination, and normalization. Today, these traits are somewhat undercut in certain sectors of the global postindustrial and networked society with its demands for new skills for the workplace, participation in emergent social and political environs, and interaction within novel forms of culture and everyday life.

A more flexible economy, based on an ever-evolving technological infrastructure and more multicultural work force demands a more technically literate, interactive, culturally sensitive, and educated work force, while revitalizing democracy requires the participation of informed citizens. ${ }^{3}$ Yet, while on one hand, the demands of the expanding global economy, culture, and polity require a more informed, participatory, and active workforce and citizenship, on the other hand, a docile workforce and service industry is still the norm in many sectors of work, society, and culture. Although for a time, ideologues of the new technologies argued that information and communication technology would of themselves dramatically reorganize and democratize the workplace, schooling, the polity, and everyday life (Gates 1996; Kelly 1995 and 1999), it is by now clear the supposed liberating effects of new technologies were greatly exaggerated. But while globalization and technological multiplication have highly ambiguous effects (Best and Kellner 2001), they providee educational reformers with the challenge of whether education will be 
restructured to promote democracy and human needs, or whether education will be transformed primarily to serve the needs of business and the global economy.

To some extent, constant technological transformation renders necessary the sort of thorough restructuring of education that radicals have demanded since the Enlightenment of Rousseau and Wollstonecraft through Dewey, all of whom saw the progressive reconstuction of education as the key to democracy. Today, however, intense pressures for change now come directly from technology and the economy and not ideology or educational reformist ideas, with an expanding global economy and novel technologies demanding innovative skills, competencies, literacies, and practices. It is therefore a burning question as to what sort of restructuring of education and society will take place, in whose interests, and for what ends. More than ever, we need philosophical reflection on the ends and purposes of education, on what we are doing and trying to achieve in our educational practices and institutions. In this situation, it may be instructive to return to Dewey and see the connections between education and democracy, the need for the reconstruction of education and society, and the value of experimental pedagogy to seek solutions to the problems of education in the present day. A progressive reconstruction of education will urge that it be done in the interests of democratization, ensuring access to information and communication technologies for all, helping to overcome the so-called digital divide and divisions of the haves and have nots, so that education is placed, as Dewey (1997 [1916]) and Freire (1972 and 1998) propose, in the service of democracy and social justice.

Yet we should be more aware than Dewey of the obduracy of divisions of class, gender, and race, and work self-consciously for multicultural democracy and education. This task suggests that we valorize difference and cultural specificity, as well as equality and shared universal Deweyean 
values such as freedom, equality, individualism, and participation. Theorizing a democratic and multicultural reconstruction of education forces us to confront the digital divide, that there are divisions between information and technology have and have nots, just as there are class, gender, and race divisions in every sphere of the existing constellations of society and culture. The latest surveys of the digital divide, however, indicate that the key indicators are class and education, as well as race and gender, hence the often-circulated argument that new technologies merely reinforce the hegemony of upper class white males must be questioned, at least for some contemporary societies. $^{4}$

Rob Shields has argued that the concept of the "digital divide" serves as a marketing device for the benefit of technology disseminators and that on the whole the development of new technologies helps increase the divide between haves and have nots (2001). While no doubt hi-tech corporations and affiliated government institutions have promoted the challenge of a digital divide the concept points to some serious problems and challenges. It is clear by now that providing access and computers alone without proper training and pedagogy does not advance education or social justice. Thus, more broadly conceived, the notion of a digital divide points to disparities in terms of access, training, skills, and the actual use of technologies to improve education and promote social justice.

With the proper resources, policies, pedagogies, and practices, educators can work to reduce the (unfortunately growing) gap between haves and have nots by promoting broad training in information and computer literacy, that embraces a wide range of projects from providing technical skills to engaging students in the production of media projects. Although technology alone will not suffice to democratize and adequately reconstruct education, in a technological society providing 
proper access and training can improve education if it is taken as a supplement. ${ }^{5}$ That is, technology itself does not necessarily improve teaching and learning, and will certainly not of itself overcome acute socio-economic divisions. Indeed, without proper re-visioning of education and without adequate resources, pedagogy, and educational practices, technology could be an obstacle or burden to genuine learning and will probably increase rather than overcome existing divisions of power, cultural capital, and wealth.

In the following reflections, I focus on the role of computers and information technology in contemporary education and the need for new pedagogies and an expanded concept of literacy to respond to the importance of information and communication technologies (ICTs) in every aspect of life. I propose some ways that ICTs and new literacies can serve as efficacious learning tools which will contribute to producing a more democratic and egalitarian society, and not just provide skills and tools to privileged individuals and groups that will improve their cultural capital and social power at the expense of others. How, indeed, can education be re-visioned and reconstructed to provide individuals and groups with the tools, the competencies, the literacies and social practices, to overcome the class, gender, and racial divides that bifurcate our society and at least in terms of economic indicators seem to be growing rather than diminishing?

First, however, I wish to address the technophobic argument against ICT per se. I have been developing critical theories of technology that call attention to uses or types of technology as tools of domination, and that rejects the hype and pretensions of techno-utopias and techno-fixes to the problems of education and society. A critical theory of technology thus sees the limitations of pedagogy and educational proposals based primarily on technology without adequate emphasis on classroom pedagogy, and on teacher and student empowerment. It insists on developing educational 
reform and restructuring to promote multicultural democracy, and calls for appropriate restructuring of technology to democratic education and society. Yet a critical theory also sees how technology can be used, and perhaps redesigned and restructured, for positive purposes such as enhancing education, democracy and overcoming the divide between haves and have nots, while enabling individuals to democratically and creatively participate in a new economy, society, and culture (see Feenberg 1991 and 1999 and Best and Kellner 2001).

The late Ivan Illich's postindustrial model of education contains a radical critique of existing schooling and alternative notions like webs of learning, tools for conviviality, and radically reconstructing education to promote learning, democracy, and social and communal life, thus providing salient alternatives to modern systems (1971, 1973). Illich's "learning webs" (1971) and "tools for conviviality" (1973) anticipate the Internet and how it might provide resources, interactivity, and communities that could help revolutionize education. For Illich, science and technology can either serve as instruments of domination or progressive ends. Hence, whereas big systems of computers promote modern bureaucracy and industry, personalized computers made accessible to the public might be constructed to provide tools that can be used to enhance learning. Thus, Illich was aware of how technologies like computers could either enhance or distort education depending on how they were fit into a well-balanced ecology of learning.

"Tools of conviviality" for Illich are appropriate, congenial, and promote learning, sociality, and community (1973). They are tools in which ends dictate means and individuals are not overpowered or controlled by their technologies (as say, with assembly lines, nuclear power plants, or giant computer systems). Convivial tools produce a democratic and convivial society 
in which individuals communicate, debate, participate in social and political life, and help make decisions. Convivial tools free individuals from dependency and cultivate autonomy and sociality. They provide individuals and society with the challenge of producing convivial tools and pedagogies that will create better modes of learning and social life.

Conviviality for Illich involves "autonomous and creative intercourse among persons, and the intercourse of persons with their environment" (1973: 27). Illich proposes a normative dimension to critique existing systems and construct alternative ones using values of "survival, justice, and self-defined work" as positive norms (1973: 13). These criteria could guide a reconstruction of education to serve the needs of varied communities, to promote democracy and social justice, and to redefine learning and work to promote creativity, community, and an ecological balance between people and the Earth. Indeed, Illich was one of the few critics working within radical pedagogy in his period who took seriously ecological issues and critically appraised institutions like schooling, medicine, transportation, and other key elements of industrial society within a broad social, political, economic, and ecological framework. His goal was nothing less than a critique of industrial civilization and a project of envisaging postindustrial institutions of learning, democratization, and social justice.

Illich saw that a glaring problem with contemporary educational institutions was that they become fixed in monomodal instruction with homogenized lesson plans, curricula, and pedagogy, and neglect to address challenging political, cultural, or ecological problems. The development of tools of conviviality and radical pedagogies enable teachers and students to break with these models and to engage in Deweyean experimental education. A reconstruction of education could help create subjects better able to negotiate the complexities of emergent forms 
of everyday life, labor, and culture, as contemporary life becomes more multifaceted and dangerous. More supportive, dialogical and interactive social relations in learning situations can promote cooperation, democracy, and positive social values, as well as fulfill needs for communication, esteem, and learning. Whereas modern mass education tended to see life in a linear fashion based on print models and developed pedagogies which broke experience into discrete moments and behavioral bits, critical pedagogies could produce skills that enable individuals to better navigate the multiple realms and challenges of contemporary life. Deweyean education focused on problem solving, goal-seeking projects, and the courage to be experimental, while Freire developed alternative pedagogies and Illich oppositional conceptions of education and learning and critiques of schooling. It is this sort of critical spirit and vision to reconstruct education and society that can help produce new pedagogies, tools for learning, and social justice for the present age.

At a time when many were enamoured of the autonomous power and emancipatory potential of the school, Illich insisted on seeing schools as part and parcel of industrial society and one of the major instruments of its social reproduction. One of Illich's enduring contributions is to see relationships between modern industrial institutions like schooling, production, medicine, transportation and other major sectors of industrial society. In order to engage with how what goes on in educational institutions we must have far better and more critical self-understandings of what specific institutions like schooling do in their institutional structure within the broader society, their hidden curriculum and how they engage in social reproduction. Understanding schooling beyond its institutional sites also requires grasping its dialectical relationships to the public pedagogies of media and the street, and the networked civic 
and social space of the Internet, as well as how schooling relates to the oppressions and operations of workplaces, government institutions, and corporations.

Illich thus provides concrete analyses and a critique of how schooling reproduces the existing social order and is flawed and debased by the defects and horrors of the industrial system. Illich also recognizes that postindustrial society requires certain competencies and that a major challenge is to construct convivial technologies that will improve both education and social life. While he resolutely opposed neo-liberal agendas and was critical of encroaching corporate domination of the Internet and information technologies, Illich's notion of "webs of learning" and "tools of conviviality" can be appropriated for projects of the radical critique and reconstruction of education and learning in the contemporary era.

It is interesting that one of the godfathers of critical pedagogy, Paulo Freire, was positive toward media and new technologies, seeing technologies as potential tools for empowering citizens, as well as instruments of domination in the hands of ruling elites. Freire wrote that: "Technical and scientific training need not be inimical to humanistic education as long as science and technology in the revolutionary society are at the service of permanent liberation, of humanization" $(1972: 157){ }^{6}$ Many critical pedagogues, however, are technophobes, seeing new technologies solely as instruments of domination and both Illich and Freire also had concerns about the Internet and globalization. In a world inexorably undergoing processes of globalization and technological transformation, one cannot, however, in good conscience advocate a policy of clean hands and purity, distancing oneself from technology and globalization, but must intervene in the processes of economic and technological revolution, attempting to deflect these forces for progressive ends and developing new pedagogies to advance the project of human liberation and well-being. 
Re-visioning technology, literacy, and education should avoid both technophobia and technophilia, rejecting technological determinism, while being critical of the limitations, biases, and downsides of new technologies, but wanting to use and redesign technologies for education for democracy and for social reconstruction in the interests of social justice. This project is also, in the Deweyean spirit, pragmatic and experimental, recognizing that there is no agreed upon way to deploy new technologies for enhancing education and democratization. Critical educators should must be prepared to accept that some of the attempts to use technology for education may well fail, as have no doubt many of our own attempts to use computer-mediated technologies for education. Different parts of the world and varying groups will have different projects that computers can help them with, different needs and problems, and thus varied pedagogical projects.

A critical theory of technological literacy is aware that technologies have unforeseen consequences and that good intentions and seemingly good projects may have results that were not desired or positive. Indeed, there are ecological consequences concerning the production, use, and discarding of computer technologies, dangers of over and misuse of computers for individual health and well-being, and costs and downsides of organizing so many activities ranging from work to communication to research around information technologies. A critical pedagogy will thus contextualize the production and use of multimedia and information technologies within social relations and contexts, criticize negative aspects and effects, and attempt to transform technologies into positive environments of education and social transformation.

Thus, the question is not whether computers and multimedia technologies are good or bad in the classroom or more broadly for education. Rather, it is a question of what multimedia and computers can do and cannot do towards helping to produce a more democratic and equalitarian 
society and what their limitations are for producing more active and creative human beings and a more just society. Crucially, we must ask: What sort of skills do students and teachers need to effectively deploy computers and information technology, what sort of effects might ICTs have on learning, subjectivities, and social relations, and what new literacies, forms of education, and social relations do we need to democratize and improve education today?

\section{Media Literacy: An Unfulfilled Challenge}

Literacy involves gaining the skills and knowledge to read and interpret the text of the world and to successfully navigate and negotiate its challenges, conflicts, and crises. Literacy is thus a necessary condition to equip people to participate in the local, national, and global economy, culture, and polity. As Dewey argued (1997), education is required to enable people to participate in democracy, for without an educated, informed, and literate citizenry, strong democracy is impossible. Moreover, there are crucial links between literacy, democracy, empowerment, and participation, and without developing adequate literacies differences between haves and have nots cannot be overcome and individuals and groups will be left out of the emerging economy, networked society, and culture.

To reading, writing, and traditional print literacies, one could argue that in an era of technological revolution, we need to develop robust forms of media literacy, computer literacy, and multimedia literacies, thus cultivating "multiple literacies" in the restructuring of education. Computer and multimedia technologies demand novel skills and competencies, and if education is to be relevant to the problems and challenges of contemporary life it must expand the concept of literacy and develop new curricula and pedagogies. 
Both traditionalists and reformists would probably agree that education and literacy are intimately connected. "Literacy" in my conception comprises gaining competencies involved in effectively using socially-constructed forms of communication and representation. Learning literacies requires attaining competencies in practices in contexts that are governed by rules and conventions. Literacies are socially constructed in educational and cultural practices involving various institutional discourses and pedagogies. Literacies evolve and shift in response to social and cultural change and the interests of elites who control hegemonic institutions.

I would resist, however, extreme claims that the era of the book and print literacy is over. Although there are discontinuities and novelties in the current constellation, there are also important continuities. Indeed, in the emergent information-communication technology environment, traditional print literacy takes on increasing importance in the computer-mediated cyberworld as people need to critically scrutinize and scroll tremendous amounts of information, putting new emphasis on developing reading and writing abilities. For instance, Internet discussion groups, chat rooms, e-mail, blogs, wikis, and various Internet forums require writing skills in which a new emphasis on the importance of clarity and precision is emerging. ${ }^{7}$ In this context of information saturation, it becomes an ethical imperative not to contribute to cultural and information overload, and to concisely communicate thoughts and feelings.

In the new multimedia environment, media literacy is arguably more important than ever. Cultural studies and critical pedagogy have begun to teach us to recognize the ubiquity of media culture in contemporary society, the growing trends toward multicultural education, and the need for media literacy that addresses the issue of multicultural and social difference. ${ }^{8}$ There is expanding recognition that media representations help construct our images and understanding of the world 
and that education must meet the dual challenges of teaching media literacy in a multicultural society and sensitizing students and publics to the inequities and injustices of a society based on gender, race, and class inequalities and discrimination. Recent critical studies see the role of mainstream media in exacerbating or diminishing these inequalities and the ways that media education and the production of alternative media can help create a healthy multiculturalism of diversity and more robust democracy. They confront some of the most serious difficulties and problems that currently face us as educators and citizens.

Yet despite the ubiquity of media culture in contemporary society and everyday life, and the recognition that the media themselves are a form of pedagogy, and despite criticisms of the distorted values, ideals, and representations of the world in popular culture, media education in K-12 schooling has never really been established and developed. The current technological revolution, however, brings to the fore more than ever the role of media like television, popular music, film, and advertising, as the Internet rapidly absorbs these cultural forms and creates new cyberspaces and forms of culture and pedagogy. It is highly irresponsible in the face of saturation by Internet and media culture to ignore these forms of socialization and education; consequently a critical reconstruction of education should produce pedagogies that provide media literacy and enable students, teachers, and citizens to discern the nature and effects of media culture.

Media culture is a form of pedagogy that teaches proper and improper behavior, gender roles, values, and knowledge of the world (Kellner, 1995). Individuals are often not aware that they are being educated and constructed by media culture, as its pedagogy is frequently invisible and subliminal. This situation calls for critical approaches that make us aware of how media construct meanings, influence and educate audiences, and impose their messages and values. A media literate 
person is skillful in analyzing media codes and conventions, able to criticize stereotypes, values, and ideologies, and competent to interpret the multiple meanings and messages generated by media texts. Media literacy helps people to use media intelligently, to discriminate and evaluate media content, to critically dissect media forms, and to investigate media effects and uses (see Kellner 1995a and 1995b).

Within educational circles, however, a debate persists over what constitutes the field of media pedagogy, with different agendas and programs. A traditionalist "protectionist" approach would attempt to "inoculate" young people against the effects of media addiction and manipulation by cultivating a taste for book literacy, high culture, and the values of truth, beauty, and justice, and by denigrating all forms of media and computer culture (see Postman 1985, 1992). A "media literacy" movement, by contrast, attempts to teach students to read, analyze, and decode media texts, in a fashion parallel to the advancement of print literacy. Media arts education in turn teaches students to appreciate the aesthetic qualities of media and to use various media technologies as instruments of self-expression and creation. Critical media literacy builds on these approaches, analyzing media culture as products of social production and struggle, and teaching students to be critical of media representations and discourses, but also stressing the importance of learning to use the media as modes of self-expression and social activism where appropriate (Kellner 1995a).

Developing critical media literacy and pedagogy also involves perceiving how media like film or video can also be used positively to teach a wide range of topics, like multicultural understanding and education. If, for example, multicultural education is to champion genuine diversity and expand the curriculum, it is important both for groups excluded from mainstream education to learn about their own heritage and for dominant groups to explore the experiences and 
voices of minority and excluded groups. Thus, media literacy can promote multicultural literacy, conceived as understanding and engaging the heterogeneity of cultures and subcultures that constitute an increasingly global and multicultural world (Courts 1998; Weil 1998).

Critical media literacy not only teaches students to learn from media, to resist media manipulation, and to use media materials in constructive ways, but is also concerned with developing skills that will help create good citizens and that will make them more motivated and competent participants in social life. Critical media literacy can be connected with the project of radical democracy and concerned to develop skills that will enhance democratization and participation. Critical media literacy takes a comprehensive approach that would teach critical skills and how to use media as instruments of social communication and change. The technologies of communication are becoming more and more accessible to young people and ordinary citizens, and can be used to promote education, democratic self-expression, and social progress. Technologies that could help produce the end of participatory democracy, by transforming politics into media spectacles and the battle of images, and by turning spectators into cultural zombies, could also be used to help invigorate democratic debate and participation (Kellner 1990, 1998).

Indeed, teaching critical media literacy could be a participatory, collaborative project. Watching television shows or films together could promote productive discussions between teachers and students (or parents and children), with emphasis on eliciting student views, producing a variety of interpretations of media texts and teaching basic principles of hermeneutics and criticism. Students and youth are often more media savvy, knowledgeable, and immersed in media culture than their teachers, and can contribute to the educational process through sharing their ideas, perceptions, and insights. On the other hand, critical discussion, debate, and analysis ought to be 
encouraged with teachers bringing to bear their critical perspectives on student readings of media material. Since media culture is often part and parcel of students' identity and most powerful cultural experience, teachers must be sensitive in criticizing artifacts and perceptions that students hold dear, yet an atmosphere of critical respect for difference and inquiry into the nature and effects of media culture should be promoted.

One of the most effective ways of teaching critical media literacy is involving students themselves in the production of media texts (see Hammer in McLaren et al 1995). Learning to produce different forms of media texts teaches codes, formal features, and the role of technology in constructing media artifacts. In becoming literate in semiological and ideological codes of media culture, students not only can read and critique dominant modes of cultural hegemony, but they can produce oppositional forms of culture, subverting the dominant codes and ideologies and providing alternatives.

A major challenge in developing critical media literacy, however, results from the fact that it is not a pedagogy in the traditional sense with firmly-established principles, a canon of texts, and tried-and-true teaching procedures. Critical media pedagogy is in its infancy; it is just beginning to produce results, and is more open and experimental than established print-oriented pedagogy. Moreover, the material of media culture is so polymorphous, multivalent, and polysemic, that it requires sensitivity to different readings, interpretations, perceptions of the complex images, scenes, narratives, meanings, and messages of media culture which in its own ways is as complex and challenging to critically decipher as book culture.

Teaching critical media literacy involves occupation of a site above the dichotomy of fandom and censor. One can teach how media culture provides significant statements or insights 
about the social world, empowering visions of gender, race, and class, or complex aesthetic structures and practices, thereby putting a positive spin on how it can provide significant contributions to education. Yet critical educators should indicate also how media culture can advance sexism, racism, ethnocentrism, homophobia, and other forms of prejudice, as well as misinformation, problematic ideologies, and questionable values, accordingly promoting a dialectical approach to the media that aims at critical and discriminating readers.

\section{Computer Literacy: An Expanded Concept}

To fully participate in the hi-tech and global society, teachers and students should cultivate new forms of computer literacy in ways that go beyond standard technical notions. Critical computer literacy involves learning how to use computer technologies to do research and gather information, as well as to perceive computer culture as a terrain containing texts, spectacles, games, and interactive multimedia which call for cultivating new literacies. As technologies like computers, telephones, televisions, and new multimedia devices converge, computer-mediated culture will increasingly provide an encompassing environment in which people work, play, relate, learn, and interact. Becoming computer-literate in this broad sense thus requires expanding notions of literacy and learning how to communicate, interact, and create in novel cybercultures.

The emergent cybercultures can be seen as a discursive and political location in which students, teachers, and citizens can all intervene, engaging in discussion groups and collaborative research projects, creating Web-sites, producing innovative multimedia for cultural dissemination, and engaging in novel modes of social interaction and learning. Computer culture enables individuals to actively participate in the production of culture, ranging from dialogue concerning 
public issues to creation of their own cultural forms. However, to take part in this culture requires not only accelerated skills of print literacy, which are often restricted to the growing elite of students who are privileged to attend adequate and superior public and private schools, but also demands multiple forms of literacy.

To respond intelligently to the dramatic technological revolution of our time, we need to begin teaching computer literacy from an early age. Computer literacy, however, itself needs to be theorized. Often the term is synonymous with technical ability to use computers, to become proficient in the use of existing programs, and maybe undertake some programming. I suggest expanding the conception of computer literacy from using computer programs and hardware to a broader concept of information and multimedia literacy. This necessitates promoting more sophisticated abilities in traditional reading and writing, as well as the capability to dissect and read cultural forms taught as part of critical media literacy and multimedia pedagogy.

In my expanded conception, computer literacy involves learning how to use computers, access information and educational material, use e-mail and list-serves, and construct Web-sites. Computer literacy comprises the accessing and processing of diverse sorts of information proliferating in the so-called "information society." It encompasses learning to find sources of information ranging from traditional sites like libraries and print media to new Internet Web-sites and search engines. Computer-information literacy involves learning where information is found, how to access it, and how to organize, interpret, and evaluate the information that one seeks.

One exciting development in the current technological revolution is that library materials and information are accessible throughout the world. To some extent, the Internet is potentially the all-encompassing library, imperfectly constructed in Alexander, Egypt, that would contain the great 
books of the world. Yet while a mind-boggling amount of the classics are found on the Internet, we still need the local library to access and collect books, journals, and print material not found on the Internet, as well as the essential texts of various disciplines and the culture as a whole. Information literacy, however, and the new tasks for librarians, also involve knowing what one can and cannot find on the Internet, how to access it, and where the most reliable and useful information is at hand for specific tasks and projects.

Information literacy also requires learning how to distinguish between good and bad information, identifying what Burbules and Callister (2000) identify as misinformation, malinformation, messed-up information, and mostly useless information. In this sense, information literacy is closely connected with education itself, with learning where information is found, how to produce knowledge and understanding, and how to critically evaluate and interpret information sources and material. It also raises questions of power and knowledge, concerning who decides that privileged information is, who gets to produce and valorize various modes of information, and whose ideas get circulated and discussed, and who gets marginalized.

Computer and information literacies also involves learning how to read hypertexts. This involves learning how to traverse the ever-changing fields of cyberculture, and to participate in a digital and interactive multimedia culture that encompasses work, education, politics, culture and everyday life. Hypertext was initially seen as an innovative and exciting new mode of writing which increased potentials for writers to explore novel modes of textuality and expression (Joyce 1995; Landow 1997). ${ }^{9}$ As multimedia hypertext developed on the Internet, it was soon theorized as a multisemiotic and multimodal form of culture. This mode is now increasingly seen as the dominant form of a new 
hyperlinked, interactive, and multimedia cyberculture (see Burbles and Callister 1996 and 2000; Snyder 1996, 1997, and 2002).

Genuine computer literacy involves not just technical knowledge and skills, but refined reading, writing, research, and communicating ability. It involves heightened capacities for critically accessing, analyzing, interpreting, processing, and storing both print-based and multimedia material. In a novel information/entertainment society, immersed in transformative multimedia technology, knowledge and information come not merely in the form of print and words, but through images, sounds, and multimedia material as well. Computer literacy thus also involves the ability to discover and access information and intensified abilities to read, to scan texts and computer data bases and websites, and to access information and images in a variety of forms, ranging from graphics, to visual images, to audio and video materials, to good old print media. The creation of new multimedia websites, data bases, and texts requires accessing, downloading, and organizing digitized verbal, imagistic, and audio and video material that are the new building blocks of multimedia culture.

Within multimedia computerized culture, visual literacy takes on increased importance. On the whole, computer screens are more graphic, multi-sensory, and interactive than conventional print fields that disconcerted many of us when first confronted with the new environments. Icons, windows, mouses, and the various clicking, linking, and interaction involved in computer-mediated hypertext dictate new competencies and a dramatic expansion of literacy. Visuality is obviously crucial, compelling users to perceptively scrutinize visual fields, perceive and interact with icons and graphics, and use technical devices like a mouse to access the desired material and field. But tactility is also important, as individuals must learn navigational skills of how to proceed from one 
field and screen to another, how to negotiate hypertexts and links, and how to move from one program to another if one operates, as most now do, in a window-based computer environment. And as voice and sound enter multimedia culture, refined hearing also becomes part of the aesthetics and pedagogies of an expanded computer literacy.

In my conception, computer literacy thus involves technical abilities concerning developing basic typing skills, mastering computer programs, accessing information, and using computer technologies for a variety of purposes ranging from interpersonal communication to artistic expression to political debate. There are ever more hybrid implosions between media and computer culture as audio and video material becomes part of the Internet, as CD-ROMs, DVDs, and multimedia develop, and as new technologies become part and parcel of the home, school, and workplace. Therefore, the skills of decoding images, sounds, and spectacle learned in critical media literacy training can also be valuable as part of computer literacy.

Moreover, with ever-expanding Internet subcultures and on-line communities, more and more people have the possibilities of participating in cultural production and expression. New web

forms of design, such as blogs and wikis ${ }^{10}$, have emerged as important new developments of the Net's hypertextual architecture and provide opportunities for new voices, alternative on-line communities, and political activism (Kahn and Kellner 2003). Participation in this new cultural and political environment accordingly requires the cultivation of multiple literacies.

\section{Multimedia and Multiple Literacies: The New Frontier}

The new multimedia environments necessitate a diversity of types of multisemiotic and multimodal interaction, involving interfacing with words and print material and often images, 
graphics, and audio and video material. As technological convergence develops apace, individuals need to combine the skills of critical media literacy with traditional print literacy and new forms of multiple literacies to access, navigate, and participate in the new multimedia hypertext environments. Literacy in this conception involves the abilities to engage effectively in sociallyconstructed emergent and novel forms of culture and communication. Reading and interpreting print was the appropriate mode of literacy for books, while critical multiple literacies entail reading and interpreting discourse, images, spectacle, narratives, and the forms and genres of media culture. Forms of multimedia communication involve print, speech, visuality, and audio, in a hybrid field that combines these forms, all of which involve skills of interpreting and critique.

The term "multiple literacies" points to the many different kinds of always proliferating literacies needed to access, interpret, criticize, and participate in the emergent multimedia forms of culture and society. ${ }^{11}$ The key root here is the "multiple," the proliferation of media and forms that demand a multiplicity of competencies and skills and abilities to access, interact, and help construct a new semiotic terrain. Multiple literacies involve reading across varied and hybrid semiotic fields and being able to critically and hermeneutically process print, graphics, moving images, and sounds. Perpetually multiplying media provide the challenge for multi-plying uses, always recreating and reconstructing media forms and practices.

The term "hybridity" suggests the combination and interaction of diverse media and the need to synthesize the various forms in an active process of the construction of meaning. Reading a music video, for instance, involves processing images, music, spectacle, and sometimes narrative in a multisemiotic activity that simultaneously draws on diverse aesthetic forms. Interacting with a Web-site, DVD, or CD-ROM often involves scanning text, graphics, moving images, and clicking 
onto the fields that one seeks to peruse and explore, looking for appropriate material. This might lead individuals to draw upon a diversity of materials in new interactive learning or entertainment environments, whereby they must simultaneously read and interpret images, graphics, animation, and text.

While traditional literacies concern practices in contexts that are governed by rules and conventions, the conventions and rules of multiliteracies are currently evolving so that their pedagogies comprise a fresh although bustling and competitive field. Multimedia sites are not entirely new, however. Multisemiotic textuality was first evident in newspapers (consider the difference between The New York Times and U.S.A. Today in terms of image, text, color graphics, design, and content) and is now evident in textbooks that are much more visual, graphic, and multimodal than the previously linear and discursive texts of old. But it is CD-ROMs, DVDs, Websites, and new multimedia that are the most distinctively multimodal and multisemiotic forms. These spaces are the new frontier of learning and literacy, the great contemporary challenge to education. Critical educators need to theorize the literacies necessary to interact in these emergent multimedia environments and to gain the skills that will enable individuals to learn, work, and create in emergent cultural spaces and domains.

Cultivating multiple literacies and reconstructing education for democratization will also involve constructing traditional pedagogies and social relations. Emergent multimedia technologies enable group projects for students and more of a problem-solving pedagogy in the spirit of Dewey and Freire than traditional transmission top-down teaching models (1972 and 1998). To enable students to access information, engage in cultural communication and production, and to gain the skills necessary to succeed in the global economy and culture, they need to acquire enhanced 
literacies, abilities to work cooperatively with others, and to navigate emergent cultural and social terrains. Such group activity may generate more egalitarian relations between teachers and students and more democratic and cooperative social relations. Of course, it also demands reconsideration of grading and testing procedures, rethinking the roles of teacher and student, and constructing projects and pedagogies appropriate to the new cultural and social environments.

Moreover, critical educators are soon going to have to rethink SATs and standard tests in relation to the new media and technologies; having the literacy and skills to successfully access material sought after, communicate, work, and create within computer and multimedia culture is quite different from reading and writing in the mode of print literacy. While traditional skills of reading and writing continue to be of utmost importance in cyberculture, they are sublated within multiliteracy, so eventually an entirely different sort of test is going to need to be devised in order to register individuals' multiple literacy competencies and to predict success in a new technological and educational environment. In this mutating global and technological world, it becomes increasingly irrational to focus education on producing higher test scores on exams that themselves are becoming obsolete and outdated by the changes in the economy, society, and culture. ${ }^{12}$

Critical pedagogies of the future must also confront the issue of on-line education, of how the new cultural terrain of cyberspace produces new sites of information, education, and culture, as well as novel on-line forms of interaction between students and teacher. In addition, possibilities of students developing their own spaces, cultural forms, and modes of interaction and communication should be promoted. The challenge will also arise of how to balance classroom instruction with online instruction, as well as sorting out the strengths and limitations of print versus on-line multimedia material (see Feenberg 1999). Indeed, the emergent ICTs and cultural spaces require us 
to rethink education in its entirety, ranging from the role of the teacher, teacher-student relations, classroom instruction, grading and testing, the value and limitations of books, multimedia, and other teaching material, and the goals of education itself.

On-line education and virtual learning also confronts us with novel problems such as copyright and ownership of educational materials; collaborations between computer programmers, artists and designers, and teachers and students in the construction of teaching material and sites; and the respective role of federal and local government, the community, corporations, and private organizations in financing education and providing the skills and tools necessary for a global economy and culture. Furthermore, the technological revolution forces a rethinking of philosophical problems of knowledge, truth, identity, and reality in virtual environments. Both philosophy and philosophy of education most be reconstructed to meet the challenges of democracy and a new hitech economy (Kellner 2003).

Finally, adequately meeting the challenges of ever-multiplying technologies raise the question of design and reconstruction of technology itself. As Andrew Feenberg has long argued (1991, 1995, 1999), democratizing technology often requires its reconstruction and re-visioning by individuals. Within the technology world, "hackers" have redesigned technological systems and much of the Internet itself is the result of individuals contributing collective knowledge and making improvements that aid various educational, political, and cultural projects. Of course, there are corporate and technical constraints in that dominant programs impose their rules and constraints on users and the open source movement has challenged users to participate in alternative computer programs and sites, freely providing new innovations, programs, and content of various modes. 
There has been an on-going struggle within computer world between corporations and users with governments usually intervening on the side of major corporations.

Critical educators, however, should help teach students and themselves to become producers as well as consumers, thus helping to redesign and reconstruct the very forms and programs of computers. There are, of course, restrictions on what those without highly developed technical knowledge can do, but within limits more creative and reconstructive uses of ICTs can be devised and implemented. This leads to some final considerations on the re-vision and reconstruction of education.

\section{Re-Visioning and Reconstructing Education in the Contemporary Era}

In sum, individuals should be helped to develop the competencies to understand, critique, and transform the social and cultural conditions in which they live, gaining the ability to be creative and transformative subjects and not just objects of domination and manipulation. This requires developing abilities for critical thinking, reflection, and the capacity to engage in discourse, cultural creation, and political action and movements. Active and engaged subjects are produced in social interaction with others, as well as with tools and techniques, so social skills and individual capacities for communication, creativity, and action must be part of the multiple literacies that a radical reconstruction of education seeks and cultivates.

Crucially, developing multiple literacies and alternative pedagogies must become reflective and critical, aware of the educational, social, and political assumptions involved in the restructuring of education and society currently underway. In response to the excessive hype concerning new technologies and education, it is important to maintain the critical dimension and to reflect upon the 
nature and effects of new technologies and the pedagogies developed as a response to their challenge. Many advocates of new technologies, however, eschew critique for a purely affirmative agenda. For instance, after an excellent discussion of new modes of literacy and the need to rethink education, Gunther Kress argues that we must move from critique to design, beyond a negative deconstruction to more positive construction (1997). But rather than following such modern logic of either/or, critical pedagogues should pursue the logic of both/and, perceiving design and critique, deconstruction and reconstruction, as complementary and supplementary rather than as antithetical choices. Certainly, we need to design alternative technologies, pedagogies, and curricula for the future, and should attempt to design more democratic and egalitarian social and pedagogical relations as well, but we need to criticize misuse, inappropriate use, overinflated claims, and exclusions and oppressions involved in the introduction of ICTs into education. The critical dimension is needed more than ever as we attempt to develop improved teaching strategies and pedagogy, and design more emancipatory and democratizing technologies and curricula. In this process, we must be constantly critical, practicing critique and self-criticism, putting in question our assumptions, discourses, and practices, as we experimentally develop novel and alternative literacies and pedagogy (see Kellner 2003).

In all educational and other experiments, critique is indeed of fundamental importance. From the Deweyean perspective, progressive education involves trial and error, design and criticism. The experimental method itself comprises critique of limitations, failures, and flawed design. In discussing new technologies and multiple literacies, we also need to constantly raise the questions: Whose interests are emergent technologies and pedagogies serving? Are they helping all social groups and individuals? Who is being excluded and why? We also need to raise the question 
both of the extent to which multiplying technologies and literacies are preparing students and citizens for the present and future and producing conditions for a more vibrant democratic society, or simply reproducing existing inequalities and inequity.

Further, creating multiple literacies must be contextual, engaging the life-world of the students and teachers participating in the new adventures of education. Learning involves developing abilities to interact intelligently with the environment and other people, and calls for vibrant social and conversational environments. Education requires doing and can be gained from practice and social interaction. One can obviously spend too much time with technologies and fail to develop basic social skills and competencies. As Rousseau, Wollstonecraft, and Dewey argued, education involves developing proficiencies that enable individuals to successfully develop within their concrete environments, to learn from practice, and to be able to interact, work, and create in their own societies and cultures. In the dynamically evolving and turbulent global culture, multiple literacies require multicultural literacies. Communicating and interacting with different groups and individuals demands being able to understand and work with a heterogeneity of people and spaces, acquiring literacies in a multiplicity of media and gaining the competencies to participate in a democratic culture and society (see Courts 1998 and Weil 1998).

From the policy perspective, it seems clear that it is the duty of the federal, state, and local government, as well as other interested parties, to provide the necessary equipment and tools to teachers, students, and schools in order to make it possible for education to cultivate the skills necessary for participation in the emergent global economy, networked society, and cyberculture. Second, it is important that teachers have proper training to make use of the technology in their classrooms and that there are labs with training or support people who have the proper skills and can 
ensure that teachers and students can effectively deploy the new media and technologies. ${ }^{13}$ Recent studies have indicated that without proper teacher training the technology itself will not do the teaching and may be a source of frustration, thus blocking the educational goals desired (see Rawls 2000 and Zimmerman 2000). Consequently, teacher training and intelligent computer lab design and use, as well as development of more intelligent and user-friendly software, is necessary to improve education in the Information Age.

But, as I have argued in this paper, teachers and students need to develop new pedagogies and modes of learning in the new information and multimedia environment. This could involve a democratization and restructuring of education such as was envisaged by Dewey, Friere, and Illich in which education is seen as a dialogical, democraticizing, and experimental practice. New information technologies encourage the sort of experimental and collaborative projects proposed by Dewey as important for progressive education (1997 [1916]). This could also involve the more dialogical relations between student and teachers envisaged by Freire in which teachers learn from students and promote collaborative, dialogical and non-authoritarian teaching methods (1972 and 1999), and Illich's conceptions of “webs of learning” and “tools for conviviality” (1971 and 1973).

This re-visioning of education involves that recognition that teachers can learn from students and that often students are ahead of teachers in various technological literacies and technical abilities. Many of us (and this is true of myself) have learned much of what we know of computers and new media and technologies from students. We should also recognize to extent to which young people helped invent the Internet and have grown up in a cyberculture in which they may have cultivated technological skills from an early age. ${ }^{14}$ Peer-to-peer communication among young 
people is highly sophisticated and developed and democratic pedagogies should build upon and enhance these resources and practices.

One of the challenges of contemporary education is to overcome the disconnect between students experiences, subjectivities, and interests rooted in the new multimedia cyberculture in contrast to the classroom situation grounded in print culture and traditional learning and disciplines (see Luke and Luke, 2002). Already in the 1960s, Marshall McLuhan (1964) pointed to the disconnect between students raised on radio, television, and popular culture confronted with print materials. Today, the disconnect is even more striking in the contrast between an interactive and multimedia cyberculture and traditional forms of authoritarian lecturing and problematic print materials, thus suggesting a generational divide as well as a digital divide.

The disconnect and divides can be overcome, however, by more actively and collaboratively bringing students into interactive classrooms or learning situations in which they are able to transmit their skills and knowledges to fellow students and teachers alike. Such a democratic and interactive reconstruction of education thus provides the resources for democratic social reconstruction, as well as cultivating the new skills and literacies needed for the global economy and cyberculture. So far, arguments for restructuring education mostly come from the high-tech and corporate sector who are primarily interested in new media and literacies and the reconstruction of education for the workforce and economy. But restructuring can serve the interests of democratization as well as the global economy. Following Dewey, we should accordingly militate for education that is aimed at producing better democratic citizens, as well as providing skills for the work place and social and cultural life. 
Further, to cultivate new literacies for democratizing education and society in the contemporary era, we need the Deweyan experimental method of trying out and testing ideas in how computers and new information technology can aid reading, research, and teaching traditional material. This involves trial and error, attempting to discern what works and what does not in using new media to democratize and enhance education. Thus, like Dewey, we need to perceive the interconnection of science, technology, education, and democracy in the present conjuncture. To have a enlivened democracy, we must have educated and informed citizens who require training in science and technology, and acquisition of new multiple literacies. Cultivating multiple literacies involves the scientific method of trial and error, seeking collaborative solutions to problems, and working together to democratically reconstruct education and society. As Dewey noted, this experimental and collaborative method is also the ethos of democracy, which involves dialogue, cooperation, and working together, as well as designing and properly using voting machines. ${ }^{15}$

It appears that technology will certainly drive the reconstruction of education, but we should make sure that it works to enhance democracy and empower individuals and not just corporations and a privileged techno-elite. Producing democratic citizens and empowering the next generation for democracy should be a major goal of the reconstruction of education in the present age. Moreover, as Freire reminds us (1972 and 1998), critical pedagogy comprises the skills of both reading the word and reading the world. Hence, multiple literacies include not only media and computer literacies, but a diverse range of social and cultural literacies, ranging from ecoliteracy (e.g. understanding the body and environment), to economic and financial literacy to a variety of other competencies that enable us to live well in our social worlds. Education, at its best, provides the symbolic and cultural capital that empowers people to survive and prosper in an increasingly 
complex and changing world and the resources to produce a more cooperative, democratic, egalitarian, and just society. Thus, with Plato, Rousseau, Wollstonecraft, Dewey, Freire, and others I see philosophy of education as reflecting on the good life and the good society and the ways that education can contribute to creating a better world. But as the world changes, so too must education that will be part of the problem or part of the solution as we enter negotiate an ever more precarious and insecure present and future.

The project of transforming education will take different forms in different contexts. In the overdeveloped countries, individuals should be empowered to work and act in a hi-tech information economy, and should learn skills of media and computer literacy to survive in the new social environment. Traditional skills of knowledge and critique should also be enhanced, so that individuals can name the system, describe and grasp the changes occurring and the defining features of the new global order, and can learn to engage in critical and oppositional practice in the interests of democratization and progressive transformation. This process challenges us to gain vision of how life can be, of alternatives to the present order, and of the necessity of struggle and organization to realize progressive goals. Languages of knowledge and critique must be supplemented by the discourse of hope and praxis.

In much of the world, the struggle for daily existence is paramount and meeting unmet human and social needs is a high priority. Yet everywhere education can provide the competencies and skills to improve one's life, to create a better society, and a more civilized and developed world. Moreover, as the entire world becomes part of a global and networked society, gaining the multiple literacies discussed in this paper becomes important everywhere as media and cyberculture become more ubiquitous and the world economy demands ever more sophisticated technical skills. 
This is a time of challenge and a time for experiment. It is time to put existing pedagogies, practices, and educational philosophies in question and to construct more democratic and progressive ones. It is a time for new pedagogical experiments to see what works and what doesn't work. It is a time to reflect on our goals and to discern what we want to achieve with education and how we can achieve it. Ironically, it is a time to return to classical philosophy of education which situates reflections on education in reflections on the good life and society at the same time that we reflect on how we can transform education to become relevant to a hi-tech society and global economy and culture. It is time to return to John Dewey to rethink that intimate connection between education and democracy at the same time we address the multicultural challenges that Dewey in the midst of a still vital melting pot ideology and liberal progressivist optimism did not address.

Most saliently, it is time to take up the Deweyean attitude of pragmatic experimentation to see what it is that the new technologies can and cannot do in order to see how they can enhance education.

In the current turbulent situation of the global restructuring of capitalism and worldwide struggles for democratization, we have for the first time in decades a chance to reconstruct education and society. In this conjuncture, technology is a revolutionizing force, whereby all political parties and candidates pay lipservice to education, to overcoming the digital divide, and to expanding literacy. The time is ripe to take up the challenge and to move to reconstruct education and society so that groups and individuals excluded from the benefits of the economy, culture, and society may more fully participate and receive opportunities not possible in earlier social constellations. 


\section{$\underline{\text { References }}$}

Atkinson, Richard C. (1999-2000) "The Future Arrives First in California," Issues in Science and Technology (Winter): 43-51.

Best, Steven, and Kellner, Douglas (2001) The Postmodern Adventure. New York: Guilford Press.

Burbules, Nicholas C. (1997) "Rhetorics of the Web: Hyperreading and Critical Literacy in Page to Screen," in Taking Literacy Into the Electronic Era, Ilana Snyder, ed. New South Wales: Allen and Unwin: 102-122.

Burbules, Nicholas C. and Callister, Thomas (1996) "Knowledge at the Crossroads: Some Alternative Futures of Hypertext Learning Environments," Educational Theory 46, No. 1 (Winter): 23-50.

Burbules, Nicholas C. and Callister, Thomas (2000) "Watch IT. The Risks and Promises of Information Technology. Boulder, Col.: Westview Press.

Carson, Diane, and Lester D. Friedman (1995) Shared Differences. Multicultural Media \& Practical

Pedagogy. Urbana and Chicago: University of Illinois Press.

Cazden, Courtney, Cope, Bill, Fairclough, Norman, Gee, James, Kalantzis, Mary, Kress, Gunter, Luke, Allan, Luke, Carmen, Michaels, Sarah \& Nakata, Martin (1996) "A Pedagogy of Multiliteracies: Designing Social Futures." Harvard Educational Review 66: 60-92.

Courts, Patrick L. (1998) Multicultural Literacies: Dialect, Discourses, and Diversity. New York: Peter Lang.

Dewey, John (1997 [1916]) Democracy and Education. New York: Free Press. 
Dines, Gail, and Jean Humez (1995), editors, Gender, Race, and Class in Media. Thousand Oaks, Ca. and London: Sage.

Duderstadt, James J. (1999-2000) "New Roles for the 21st Century University," Issues in Science and Technology (Winter): 37-44.

Feenberg, Andrew (1991) Critical Theory of Technology. New York: Oxford University Press.

(1995) Alternative Modernity. Berkeley: University of California

Press.

(1999) Questioning Technology. New York and London, Routledge.

Fleming, Dan (1993) Media Teaching. Oxford: Basil Blackwell.

Freire, Paulo (1972) Pedagogy of the Oppressed. New York: Herder and Herder. (1998) A Paulo Freire Reader. New York: Herder and Herder.

Giroux, Henry (1992) Border Crossing. New York: Routledge.

(1993) Living Dangerously. Multiculturalism and the Politics of

Difference. New York: Peter Lang.

(1994) Disturbing Pleasures. New York: Routledge.

(1996) Fugitive Cultures: Race, Violence, and Youth. New York: Routledge.

Giroux, Henry and Peter McLaren (1994), editors, Between Borders. Pedagogy and the Politics of Cultural Studies. New York: Routledge.

Giroux, Henry and Patrick Shannon (1997) Education and Cultural Studies. London and New York: Routledge.

Illich, Ivan (1971) Deschooling Society. New York: Harper and Row. 
(1973) Tools for Conviviality. New York: Harper and Row.

Illich, Ivan. and Sanders, Barry (1988) ABC: The Alphabetization of the Popular Mind, San Francisco: North Point Press.

Joyce, Michael (1995) Of Two Minds: Hypertext Pedagogy and Poltics. Ann Arbor: University of Michigan Press.

Kahn, R. and Kellner, D. (2003) "Internet Subcultures and Oppositional Politics", in D. Muggleton (ed), The Post-subcultures Reader, London: Berg.

Kellner, Douglas (1995a) Media Culture. London and New York: Routledge. (1995b) "Cultural Studies, Multiculturalism, and Media Culture." In Dines and Humez 1995: 5-17. (1998) "Multiple Literacies and Critical Pedagogy in a Multicultural Society," Educational Theory, Vol. 48, Nr. 1 (1998): 103-122. (1999) "Multiple Literacies and Critical Pedagogy in a Multicultural Society," in The Promise of Multiculturalism, edited by George Katsiaficas and Teodros Kiros. New York and London: Routledge: 211-236 (2000) "Globalization and New Social Movements: Lessons for Critical Theory and Pedagogy," in Globalization and Education, edited by Nicholas Burbules and Carlos Torres. New York: Routledge. (2003) “Toward a Critical Theory of Education," Democracy and Nature, Vol. 9, Nr. 1 (March): 51-64. Kellner, Douglas and Michael Ryan (1988) Camera Politica: The Politics and Ideology of Contemporary Hollywood Film. Bloomington, Ind: Indiana University Press. 
Kress, Gunther (1997) "Visual and verbal modes of representation in electronically mediated communication: the potentials of new forms of text," in Snyder 1997: 53-79.

Landow, George (1992) Hypertext. The Convergence of Contemporary Critical Theory and

Technology. Baltimore and London: Johns Hopkins University Press; second edition, Hypertext 2.0 (1997).

Lehmann, Nicholas (1999) The Big Test: The Secret History of the American Meritocracy. New York: Farrar Straus \& Giroux.

Luke, Allan and Carmen Luke (2002) “Adolescence Lost/Childhood Regained: On Early Intervention and the Emergence of the Techno-Subject," Journal of Early Childhood Literacy, Vol 1 (1): 91-120.

Luke, Carmen (1996) "Reading Gender and Culture in Media Discourses and Texts," in G. Bull and M. Anstey (Eds.), The Literacy Lexicon. New York and Sydney: PrenticeHall.

(1997a) Technological Literacy. Melbourne: National Languages \& Literacy Institute. Adult Literacy Network.

(1997b) "Media Literacy and Cultural Studies," in Constructing Critical Literacies, edited by Sandy Muspratt, Allan Luke and Peter Freebody. Cresskill, N.Y.: Hampton Press: 19-50.

Masterman, Len (1989 [1985]) Teaching the Media. London and New York: Routledge.

McLaren, Peter, Rhonda Hammer, David Sholle and Susan Reilly, (1995) Rethinking Media Literacy. A Critical Pedagogy of Representation. New York: Peter Lang. McLuhan, Marshall (1962) The Gutenberg Galaxy. New York: Signet Books. 
(1964) Understanding Media: The Extensions of Man. New York:

Signet Books.

Ong, Walter (1988) Orality and Literacy: The Technologizing of the Word. London and New York: Routledge.

Postman, Neil (1985) Amusing Ourselves to Death. New York: Viking-Penquin. (1992) Technopolis: The Surrender of Culture to Technology. New York:

Random House.

Rawls, Jennifer Janofsky (2000) The Role of Micropolitics in School-Site Technology Efforts: A Case Study of the Relationship Between Teachers and the Technology Movement at their School. Ph.D. Dissertation, UCLA.

Robins, Kevin and Frank Webster (1999) Times of the Technoculture. New York: Routledge.

Semali, Ladislau and Ann Watts Pailliotet (1999) Intermediality. Boulder, Col.: Westview.

Schwoch, James, Mimi White, and Susan Reilly (1992) Media Knowledge. Albany: State University of New York Press.

Sholle, David and Stan Denski (1994) Media Education and the (Re)Production of Culture. Westport, Conn.: Bergin \& Garvey.

Snyder, Ilana (1996) Hypertext: The Electronic Labyrinth. Melbourne and New York: Melbourne University Press and New York University Press. (1997) ed. Page to Screen: Taking Literacy into the Electronic Era. New South Wales: Allen and Unwin. (2002) ed. Silicon Literacies. London and New York: Routledge. 
Webster, Frank (1995) Theories of the Information Society. London and New York:

Routledge.

Weil, Danny K. (1998) Toward a Critical Multicultural Literacy. New York: Peter Lang.

Wollstonecraft, Mary (1988) A Vindication of the Rights of Woman. New York: Norton.

Zimmerman, Roy (2000) The Intersection of Technology and Teachers: Challenges and Problems.

Ph.D Dissertation, UCLA.

$\underline{\text { Notes }}$

${ }^{1}$ An earlier and substantially different version of this study appeared in Educational Theory (Kellner 1998) and I am grateful to its editor Nicholas Burbules for helpful criticism and ongoing discussion of technology and literacy. Yet another version was presented at UCLA in February 26, 1998 at my Kneller Chair Inaugural Lecture and I am grateful to members of the audience for discussion of the issues developed here. The paper was also presented at the Philosophy of Education Society convention in Toronto on April 1, 2000 and I am grateful to this audience for vigorous polemic and to commentator Nicholas Burbules for constructive critique and discussion. I was also able to refine ideas in this paper at the October 2000 PacBell/UCLA conference on information literacy and at the California Association for the Philosophy of Education (CAPE) meetings at UCLA the same month and am also thankful to audiences at these events for constructive commentary and discussion, especially Aimee Dorr and Howard Besser who organized the Pac-Bell/UCLA conference and participated in CAPE discussions. Later versions were published in a Routledge volume on multiculturalism, edited by George Katsiaficas and Teodros Kiros, Silicon Literacies, edited by Ilana Snyder (Kellner 1999 and 2002) and I am thankful to the editors for comments and discussions which helped with clarification of my position on multiculturalism and education and on "silicon literacies." For continuing discussions of the issues in this paper I am especially grateful to Rhonda Hammer, Allan and Carmen Luke, and Richard Kahn.

2. For materials pertaining to the educational reform proposed by Dewey and Freire and the broader conceptions of relating education to creation of the good life and good society advanced by Plato, Rousseau, Wollstonecraft, and others which inform this paper, see my philosophy of education web site, accessible from

www.gseis.ucla.edu/faculty/kellner/kellner.html. See also my Education and Technology web site which contains materials pertinent to this study.

${ }^{3}$ Studies reveal that women, minorities, and immigrants now constitute roughly 85 percent of the growth in the labor force, while these groups represent about 60 percent of all workers; see 
Duderstadt 1999-2000: 38. In the past decade, the number of Hispanics in the United States increased by 35 percent and Asians by more than 40 percent. Since 1991, California has had no single ethnic or racial minority and almost half of the high school students in the state are AfricanAmerican or Latino. Meanwhile, a "tidal wave" of children of baby boomers are about to enter college; see Atkinson 1999-2000: 49-50. Obviously, I am writing this study from a U.S. perspective, but would suggest that my arguments have broader reference in an increasingly globalized society marked by a networked economy, increasing migration and multiculturalism, and a proliferating Internet-based cyberculture. There is by now a tremendous amount of books and articles on the new economy, technological revolution, new cultural spaces, and the implications for every aspect of life from education to war. See, for example, the monumental studies by Castells 1996, 1997, and 1998, and the analyses of the restructuring of capital, technological revolution, and the postmodern turn in Best and Kellner, 2001.

4. The "digital divide" has emerged as the buzzword for perceived divisions between information technology have and have nots in the current economy and society. A U.S. Department of Commerce report released in July 1999 claimed that digital divide in relation to race is dramatically escalating and the Clinton administration and media picked up on this theme (See the report "Americans in the Information Age: Falling Through the Net" at http://www.ntia.doc.gov/ntiahome/digitaldivide/). A critique of the data involved in the report emerged, claiming that it was outdated; more recent studies by Stanford University, Cheskin Research, ACNielson, and the Forester Institute claim that education and class are more significant factors than race in constructing the divide (see http:cyberatlas.internet.com/bigpicture/demographics for a collection of reports and statistics on the divide). In any case, it is clear that there is a gaping division between information technology haves and have nots, that this is a major challenge to developing an egalitarian and democratic society, and that something needs to be done about the problem. My contribution involves the argument that empowering the have nots requires the dissemination of new literacies and thus empowering groups and individuals previously excluded from economic opportunities and socio-political participation.

${ }^{5}$ See the Ph.D. dissertations by two of my UCLA students, Jennifer Janofsky Rawls 2000 and Roy Zimmermann 2000. See also Bernard Warner, "Computers for Youth: Spreading the Net," The Standard, March 27, 2000 which reports: "A study conducted recently by Denver-based Quality Education Data showed school districts across the country spent $\$ 6.7$ billion on technology in the 1998-1999 school year, up almost 25 percent from the previous year. But the same study revealed that an equally crucial funding component -- computer training for teachers -- was startlingly low, rising just 5.2 percent over the same period." In June 2000, however, President Bill Clinton argued for increased funding for teaching training to use new technologies so it appears that there is growing recognition of the problem.

". Freire also stated that: "It is not the media themselves which I criticize, but the way they are used" (1972: 136). Moreover, he argued for the importance of teaching media literacy to empower individuals against manipulation and oppression, and using the most appropriate media to help teach the subject matter in question (114-116). 
${ }^{7}$ On the new forms of Internet culture and on-line communities, see Kahn and Kellner 2003. 8. For an earlier and expanded discussion of media literacy, see Kellner 1998. Carson and Friedman 1995 contains studies dealing with the use of media to deal with multicultural education. Examples of teaching media literacy which I draw on include Masterman 1985; Kellner and Ryan 1988; Schwoch, White and Reilly 1992; Fleming 1993; Giroux 1992, 1993, 1994, and 1996; Giroux and McLaren 1994; Sholle and Densky 1994; McLaren, Hammer, Sholle, and Reilly 1995; Kellner 1995a and 1995b; Luke 1996, 1997a and 1997b; Giroux and Shannon 1997; Potter 1998; and Semali and Watts Pailliotet 1999. See also the work of Barry Duncan and the Canadian Association for Media Literacy (website: http://www.nald.ca/province/que/litcent/media.htm) and the Los Angeles based Center for Media Literacy (www.medialit.org). It is a scandal that there are not more efforts to promote media literacy throughout the school system from K-12 and into the University. Perhaps the ubiquity of computer and multimedia culture will awaken educators and citizens to the importance of developing media literacy to create individuals empowered to intelligently access, read, interpret, and criticize contemporary media and cyberculture.

${ }^{9}$ Some early advocates of hypertext attacked the emergence of the World Wide Web as a debased medium which brought back into play the field of earlier media, like television, forcing the word to renegotiate its power against the image and spectacles of sight and sound, once again decentering the written word (see, for instance, Joyce 1997 and the discussion in Landow 1992 and 1997; see also their more recent reflections in Sydner 2002). As the Internet becomes a multimedia hypertext, however, it is clear that contemporary education must teach reading a multimodal hypertext as a basic skill and mode of literacy.

${ }^{10}$ On blogs and wikis, see Kahn and Kellner 2003. "Blogs" are hypertextual web logs which people use for new forms of journaling, self-publishing, and media/news-critique, as we discuss in detail below. For examples, see our two blogs: BlogLeft: Critical Interventions, $<$ www.gseis.ucla.edu/courses/ed253a/blogger.php > (Accessed July 2003). Vegan Blog: The (Eco)Logical Weblog, <getvegan.com/blog/blogger.php> (Accessed July 2003).

"Wikis" (from the Hawaiian word for "quick") are popular new forms of group databases and hypertextual archives.

11. For other recent conceptions of multimedia literacy that I draw upon here, see the discussions of literacies needed for reading hypertext in Burbules and Callister 1996 and 2000; the concept of multiliteracy in the New London Group 1996 and Luke 1997; the papers in Snyder 1997 and 2002; Semali and Watts Pailliotet 1999; and books being published in David Barton's Routledge series "literacies" that include Illana Synder's "silicon litercies," as well as books on "city literacies, "situated literacies," "multiliteracies," and "global literacies and the World-Wide Web."

12. On the centrality of preparation for exams in contemporary education and the role of standardized tests in the U.S. educational and social system, see Lemann 1999. While I have not myself researched the policy literature on this issue, in the many discussions of SAT tests and their biases which I have read, I have not encountered critiques that indicate the obsolescence of many standardized tests in a new technological environment and the need to come up with new testing procedures based on the new cultural and social fields that we are increasingly immersed in. I would 
predict that proposals for devising such tests will emerge and that this issue will be hotly debated and contested in the future.

${ }^{13}$ It was at one time encouraging that computers and new technologies were getting into the schools in the U.S. and elsewhere at an impressive rate. The September 25, 2000 US News \& World Report notes that in 1994 when President Clinton vowed to connect every school to the information superhighway, only 1 in 3 schools, and just 3\% of the classrooms, were wired to the Internet. But by 1999, according to the National Center for Education Statistics, 95\% of schools and 63\% of classrooms had Internet access. A survey then showed that $76 \%$ of the public polled believed that US government should support efforts to train teachers to use new technologies in their classrooms, and that those surveyed said that they saw new technologies and gaining necessary literacies and skills as essential to their own professional and personal advancement, that $71 \%$ thought that the Internet could enhance their own educational level, while $86 \%$ thought that the net could help their children learn more and that $71 \%$ claimed that they had gone online for educational reasons--up from $36 \%$ when same group was polled in 1999. Yet it is discouraging that the Bush administration has not continued the progressive technology and education policies of the previous administration and has reverted to conservative schooling based on training for tests and centering on traditional forms of literacy and curricula.

${ }^{14}$ For instance, Mosaic, Netscape and the first browsers were invented by young computer users, as were many of the first Websites, list-serves, chat rooms, and so on. A hacker culture emerged that was initially conceptualized as a reconfiguring and improving of computer systems, related to design, system and use, before the term became synonymous with theft and mischief, such as setting loose worms and viruses (see Levy 1991). On youth and Internet subcultures, see Kahn and Kellner 2003.

${ }^{15} \mathrm{I}$ am, of course, ironically pointing to the non-functioning of voting technology and the system of democracy in the 2000 US Presidential election, suggesting a massive disconnect between the hitech economy and cyberculture and traditional voting machines and practices that helped the Bush machine to gain the presidency (see Kellner 2001). 